\section{Glucose-6-Phosphate Dehydrogenase deficiency presented with convulsion: a rare case}

\author{
Alparslan Merdin, ${ }^{1}$ Fatma Avci, ${ }^{1}$ \\ Nihal Guzelay ${ }^{2}$ \\ ${ }^{1}$ Department of Internal Medicine and \\ 2Department of Neurology, Akdeniz \\ University Hospital, Antalya, Turkey
}

\begin{abstract}
Red blood cells carry oxygen in the body and Glucose-6-Phosphate Dehydrogenase protects these cells from oxidative chemicals. If there is a lack of Glucose-6-Phosphate Dehydrogenase, red blood cells can go acute hemolysis. Convulsion is a rare presentation for acute hemolysis due to Glucose-6Phosphate Dehydrogenase deficiency. Herein, we report a case report of a Glucose6-Phosphate Dehydrogenase deficiency diagnosed patient after presentation with convulsion. A 70 year-old woman patient had been hospitalized because of convulsion and fatigue. She has not had similar symptoms before. She had ingested fava beans in the last two days. Her hypophyseal and brain magnetic resonance imaging were normal. Blood transfusion was performed and the patient recovered.
\end{abstract}

\section{Introduction}

Glucose-6-Phosphate Dehydrogenase (G6PD) deficiency is an inherited, $\mathrm{X}$ Chromosome-linked, metabolic disorder. G6PD deficiency is known to be the most common enzyme disorder in humans. Its frequency has been reported in a wide range.

Glucose-6-phospate dehydrogenase (G6PD) is an intracellular protective enzyme against oxidative stress. ${ }^{1}$ Its reduced concentration renders erythrocytes susceptible to hemolysis under oxidative conditions such as ingestion of fava beans or certain drugs such as chloramphenicol, sulfonamides, analgesics, isoniasid and antimalarial drugs. ${ }^{2}$ Most individuals with G6PD deficiency are asymptomatic. Besides, acute hemolysis in G6PD deficiency can manifest as fatigue, back pain, anemia, and jaundice. Here we report a patient diagnosed with G6PD deficiency after a convulsion attack which is a rare firstly presentation for G6PD deficiency.

\section{Case Report}

A 70-year-old female patient presented to the emergency department of Akdeniz University Medical Faculty Hospital (Turkey) with a complaint of fatigue. The patient had generalized tonic-clonic seizures while she was in the emergency department; but spontaneously regressed in the follow-up. In the physical examination, the patient had no hepatosplenomegaly, peripheral lymphadenopathy, and there were no signs of jaundice.

During the follow-up, she was oriented and cooperative. Her body temperature was 36.8 degrees Celsius. The patient's brain MRI (magnetic resonance imaging) and diffusion MRI of the brain showed normal findings. The patient's laboratory findings were as follows: hemoglobin: $8.5 \mathrm{~g} / \mathrm{dL}(12-16 \mathrm{~g} / \mathrm{dL})$, number of red blood cells: $2.5 \mathrm{million} / \mathrm{mm}^{3}$ (4-6), LDH: $685 \mathrm{U} / \mathrm{L}$ (135-214 U/L), direct bilirubin: 0.45 $\mathrm{mg} / \mathrm{dL}(0-0.2 \mathrm{mg} / \mathrm{dL})$, total bilirubin: $6.67 \mathrm{mg} / \mathrm{dL}$ (0.1-1.2 mg/dL), reticulocytes $4.5 \%$ (0.5-1.5), creatinine: $\quad 0.7 \mathrm{mg} / \mathrm{dL} \quad(0.7-1.2 \mathrm{mg} / \mathrm{dL})$, platelets: $\quad 344,000 /$ microliter $\quad(150,000$ 450,000/microliter), sodium: $140 \mathrm{mEq} / \mathrm{L}$ (136$145 \mathrm{mEq} / \mathrm{L})$, potassium: $4.2 \mathrm{mEq} / \mathrm{L} 3.5-5.1$ $\mathrm{mEq} / \mathrm{L})$, albumin $4.2 \mathrm{~g} / \mathrm{dL}(3.9-4.9 \mathrm{~g} / \mathrm{dL})$, and calcium: $\quad 9.8 \mathrm{mg} / \mathrm{dL} \quad(8.4-10.2 \mathrm{mg} / \mathrm{dL})$. Normochromic-normocytic erythrocytes were present in the peripheral blood smear, while no atypical cells and blasts were present. There was no visible schistocytes and fragmentation. Negative direct Coombs and negative indirect Coombs tests were noted. The patient's other laboratory findings were within normal ranges. The patient was hospitalized to find the etiology of her symptoms and 2 units erythrocyte suspension was given to the patient. The clinical electroencephalography was evaluated as normal, and as the patient had no seizure recurrence, her convulsion episodes were associated with acute symptomatic anemia by the department of neurology.

The hemoglobin electrophoresis test of the patient showed normal results. The patient's hemoglobin level increased to $11.6 \mathrm{~g} / \mathrm{dL}$ after transfusion but decreased again to $7.5 \mathrm{~g} / \mathrm{dL}$ immediately in two days. The patient's history revealed recent ingestion of broad beans two days prior to attending the emergency service. The blood test results showed low levels of glucose-6-phosphate dehydrogenase (G6PD), which was $1.7 \mathrm{IU} / \mathrm{g} \mathrm{Hb}$ (4-10) and which was measured after transfusion. After 72 hours (the third day), 2 units of erythrocyte suspension was given again to the patient and the patient's hemoglobin level increased to $\mathbf{1 0 . 9}$ with decreased bilirubin levels (direct bilirubin: $0.19 \mathrm{mg} / \mathrm{dL}$; total bilirubin: $0.48 \mathrm{mg} / \mathrm{dL}$ ); therefore, the patient was discharged with improved symptoms. She was followed-up in hematology outpatient clinic. The patient's
Correspondence: Alparslan Merdin, Department of Internal Medicine, Akdeniz University Hospital, Dumlupinar Boulevard Campus, 07059 Antalya, Turkey.

Tel.: +90.242.227.2752 - Fax: +90.242 .227 .2753$

E-mail: alparslanmerdin@yahoo.com

Key words: convulsion, fava bean ingestion, Glucose-6-Phosphate Dehydrogenase deficiency.

Acknowledgements: we would like to express our gratitude towards to our colleagues in evaluating this patient in the hospital.

Contributions: the authors contributed equally.

Conflict of interests: the authors declare no potential conflict of interests.

Received for publication: 25 December 2013. Revision received: 11 February 2014. Accepted for publication: 24 March 2014.

This work is licensed under a Creative Commons Attribution NonCommercial 3.0 License (CC BYNC 3.0).

(C) Copyright A. Merdin et al., 2014

Licensee PAGEPress, Italy

Hematology Reports 2014; 6:5266

doi:10.4081/hr.2014.5266

glucose-6-phosphate dehydrogenase level was checked during her hematology outpatient follow-up and the level was found $3.4 \mathrm{IU} / \mathrm{g} \mathrm{Hb}$ (410 ) with a normal reticulocyte count of $1.37 \%$ (0.5-1.5).

\section{Discussion and Conclusions}

G6PD deficiency is very common in Arabian Peninsula, Turkey, Middle East and Africa. This metabolic abnormality may have a possible protective effect against malaria. Patients become naturally immune to malaria. Plasmodium causes malaria by infecting red blood cells. G6PDD leads to the breakdown of red blood cells along with plasmodium. Favism which means fatigue and similar symptoms after the ingestion of fava beans is also used instead of G6PDD. All individuals with favism show G6PD deficiency. However, not all individuals with G6PD deficiency show favism. Favism has been known from ancient times. Even the great mathematician Pythagoras advised his disciples to abstain from eating broad or fava beans.

Presenting with convulsions is very rare at the initial diagnosis of G6PD deficiency. Hemolysis due to lack of G6PD is also not one of the many known causes of convulsion. There are some case reports in literature pre- 
senting this condition. ${ }^{1}$ In our case, the patient developed weakness and seizures due to hemolysis secondary to enzyme deficiency. Patient did not have similar symptoms before. We treated her with blood transfusion and her symptoms revealed immediately and recommended her not to consume fava beans. In conclusion, G6PDD should always be kept in mind in patients presenting with convulsion and anemia, especially in the people from Mediterranean basin countries.

\section{References}

1. Fayyazi A, Khajeh A, Esfahani H. Seizure as the first presentation of glucose-6-phosphate dehydrogenase deficiency in a 3year-old child. Iran J Child Neurol 2012; 6:45-7.

2. Cappellini MD, Fiorelli G. Glucose-6-phosphate dehydrogenase deficiency. Lancet 2008; 371:64-74. 